\title{
УДОСКОНАЛЕННЯ ПРОЦЕСУ НАВЧАННЯ ТЕХНІКИ УДАРУ НОГОЮ НАЗАД «УШИРО ГЕРІ КЕКОМІ»
}

\author{
Єгор Міненко $^{1 \mathrm{ABCD}}$, Світлана Марченко ${ }^{1 \mathrm{ABCD}}$
}

${ }^{1}$ Харківський національний педагогічний університет імені Г.С. Сковороди

Authors' Contribution: A - Study design; B - Data collection; C - Statistical analysis; D - Manuscript Preparation; E - Funds Collection

DOI: $10.17309 / \mathrm{jltm} .2021 .2 .06$

\begin{abstract}
Анотація
Мета дослідження - обгрунтувати вплив різних варіантів виконання вправ, а саме: кількості підходів $\left(\mathrm{X}_{1}\right)$ та інтервалів відпочинку $\left(\mathrm{X}_{2}\right)$ на засвоєння техніки виконання удару ногою назад з розворотом «уширо гері» хлопців 10 років.

Матеріали і методи. У дослідженні взяли участь 32 хлопці 10 років. Діти та їхні батьки були інформовані про всі особливості дослідження і дали згоду на участь в експерименті. Для вирішення поставлених завдань були використані методи дослідження: вивчення та аналіз науково-методичної літератури, педагогічне спостереження, хронометраж навчальних завдань, педагогічний експеримент, методи математичної статистики, методи математичного планування експерименту. У процесі навчання використовувався метод алгоритмічних розпоряджень.

Результати. Пояснюючі змінні $\left(\mathrm{X}_{1}, \mathrm{X}_{2}\right)$ відіграють свою певну роль у зміні показника навченості вправі «Удар ногою назад з розворотом «уширо гері» (Y) протягом усього експерименту. Перевірка на адекватність за критерієм Фішера показала що розраховані коефіцієнти регресії статистично значимі (Fp<Fкр). Дисперсійний аналіз виявив процентний вплив кожної пояснюючої змінної $\left(\mathrm{X}_{1}, \mathrm{X}_{2}\right)$ в усіх серіях програми навчання удару ногою назад з розворотом «уширо гері»: 1 серія - $\mathrm{X}_{1}(83,4 \%), \mathrm{X}_{2}(15,9 \%) ; 2$ серія - $\mathrm{X}_{1}(42,2 \%), \mathrm{X}_{2}(33,0 \%) ; 3$ серія $-\mathrm{X}_{1}(62,4 \%), \mathrm{X}_{1} \mathrm{X}_{2}(37,5 \%) ; 4$ серія - $\mathrm{X}_{1}(52,6 \%), \mathrm{X}_{1} \mathrm{X}_{2}(28,5 \%) ; 5$ серія - $\mathrm{X}_{1}(74,8 \%), \mathrm{X}_{2}(22,2 \%) ; 6$ серія - $\mathrm{X}_{1}(80,29 \%)$, $\mathrm{X}_{2}(12,26 \%)$.

Висновки. Максимальний ефект результативної ознаки (Y) у серіях завдань розробленої програми навчання удару ногою «уширо гері кекомі» був отриманий від наступних режимів виконання фізичних вправ: 1 серія - 4 підходи, інтервал відпочинку 60 c; 2 серія - 4 підходи, інтервал відпочинку 60 c; 3 серія - 4 підходи, інтервал відпочинку 120 c; 4 серія - 4 підходи, інтервал відпочинку 120 c; 5 серія - 4 підходи, інтервал відпочинку 120 с; 6 серія - 4 підходи, інтервал відпочинку 120 c.

Ключові слова: хлопці, навчання, фізичні вправи, програмоване навчання, режими виконання вправ, карате, удар ногою, уширо гері.
\end{abstract}

\section{Вступ}

Навчання в кіокушинкай карате - складний педагогічний процес, спрямований на системне засвоєння раціональних способів управління своїми рухами, придбання необхідних навичок і вмінь, а також пов'язаних 3 цим процесом знань. Удосконалення техніко-тактичної майстерності бійця вимагає сучасних підходів до інтенсифікації підготовки.

Вітчизняними (Марченко \& Коваленко, 2020; Марченко \& Тараненко, 2020) та зарубіжними авторами (Coral Falcó \& Isaac Estevan, 2015; Агафонов, Осколков, \& Москвичев, 2015; Estevan, Falco, Elvira, \& Vera-Garcia,

(c) Minenko, Ye., \& Marchenko, S., 2021.
2015) ведеться активна робота з пошуку шляхів для істотного підвищення рівня технічної підготовленості спортсменів. На основі якої формуються високі резерви для зростання спортивної майстерності.

Більшість дослідників визначають біомеханічну оптимізацію рухів та виявляють фактори, що впливають на навички вдосконалення ударів ногами (Wąsik \& Góra, 2016; Gavagan \& Sayers, 2017; Błaszczyszyn, Szczęsna, Pawlyta, Marszałek, \& Karczmit, 2019). Така експертиза дозволяє ефективно використовувати показники параметрів рухів, а також опрацьовувати та покращувати процес навчання. Агафонов, Осколков, \& Москвичев (2015) звертають увагу на те, що в одноборствах підбір і послідовність застосування тренувальних засобів базується на багаторічному емпіричному досвіді тренерів. 
Автори (Агафонов, Осколков, \& Москвичев, 2015; Falcó \& Estevan, 2015; Burke, al-Adawi, Burke, Bonato, \& Leong, 2017) рекомендують будувати модель навчання техніці ударів ногами базуючись на врахуванні раціональних кінематичних і динамічних параметрів рухів.

Огляд сучасних досліджень указує, що програмоване навчання слід вважати одним з найбільш ефективних сучасних підходів (Khudolii, Kapkan, Harkusha, Marchenko, \& Veremeenko, 2020; Марченко \& Тараненко, 2020; Ivashchenko, Iermakov, \& Khudolii, 2021 та інші). Високі можливості та ефективність використання множинного регресійного аналізу для розрахунку оптимальних моделей чергування фізичних вправ та інтервалів відпочинку у навчальному процесі школярів обгрунтовано Марченко (2017), Khudolii, Ivashchenko, Iermakov, Nosko, \& Marchenko (2019), Ivashchenko, Iermakov, \& Khudolii (2021). За допомогою методу моделювання Марченко \& Коваленко (2020), Марченко \& Тараненко (2020) вивчали специфіку навчання техніці ударам ногами в кіокушинкай карате.

На сьогоднішній час недостатньо обгрунтована методика навчання техніці удару ногою «уширо гері кекомі» в кіокушинкай карате на спортивно-оздоровчому етапі. Потребує дослідження вплив різних варіантів виконання вправ в залежності від обраних пояснюючих змінних «кількості підходів» та «інтервалів відпочинку».

Мета дослідження - обгрунтувати вплив різних варіантів виконання вправ на засвоєння техніки удару ногою назад з розворотом «уширо гері кекомі».

\section{Матеріали і методи}

\section{Учасники дослідження}

У дослідженні взяли участь 32 хлопці 10 років. Вони були рандомно розподілені на чотири групи по вісім чоловік в кожній. Діти та їхні батьки були інформовані про всі особливості дослідження і дали згоду на участь в експерименті.

\section{Організачія дослідження}

Для вирішення поставлених завдань були використані методи дослідження: вивчення та аналіз науково-методичної літератури, педагогічне спостереження, хронометраж навчальних завдань, педагогічний експеримент, методи математичної статистики, методи математичного планування експерименту. У процесі навчання використовувався метод алгоритмічних розпоряджень.

Програма навчання техніці удару ногою назад «уширо гері» з розворотом на $180^{\circ}$ через переднє плече включала серії навчальних завдань.

Перша серія навчальних завдань - вправи для розвитку рухових здібностей:

Із стійки ноги нарізно, руки на поясі, праву (ліву) ногу зігнути і підняти уперед, коліно на рівні поясу, п'ятка торкається коліна опорної ноги, пальці ніг напружені та підняті вгору. Утримувати стійке положення до 25 секунд.

Із стійки на одній нозі, друга зігнута у коліні як у попередній вправі. Через 5 с після утримання статичної пози дається команда зробити оберт на $180^{\circ}$ в сторону піднятої ноги. Після повороту утримувати рівновагу 5 с. Продовжити обертання на $180^{\circ}$ у тому ж напрямку. Після утримання рівноваги 5 с змінити ногу. Виконати 5 циклів кожною ногою. Циклом вважається обертання на $360^{\circ}$.

Друга серія навчальних завдань - вихідні і кінцеві положення:

Стійка ноги нарізно лівою (правою) вперед (куміте дачі) - ноги розведені на ширину плеч, напівзігнуті, ступні розташовані паралельно, одна нога попереду, друга - позаду, відстань між п’яткою лівої (правої) ноги і носком правої (лівої) - середній крок, гомілка лівої ноги перпендикулярна підлозі, ступня повністю спирається на підлогу, права ступня торкається підлоги лише носком, тулуб у положенні $45^{\circ}$ ліве (праве) плече уперед, голова дещо нахилена вперед, підборіддя притиснуте до ключиці, вага тіла розподілена рівномірно на обидві ноги, кулак лівої руки на рівні плечового суглоба, лікоть опущений, права рука вільно розташована біля правого боку лікоть опущений, кулак біля підборіддя. Пересування у стійці «куміте дачі» кроком вперед, назад.

Третя серія навчальних завдань - дії без яких неможливо виконати вправу:

Із стійки «куміте дачі» поступово виконати фази удару ногою «уширо гері кекомі»: фаза обертання перед початком удару, фаза виносу стегна (фаза групування перед нанесенням удару), фаза удару та контакту з ціллю, фаза повернення і збору ноги у фазу групування після нанесення удару, фаза обертання тулуба і постановкою ноги у вихідне положення. Синхронізація фази обертання з фазою удару, забезпечує більшу силу атаки. Час атаки, відстань до цілі, висота також впливають на результативність удару.

Четверта серія навчальних завдань - навчання умінню управляти рухами:

Зміна положення області таза. Із упору присівши стопи на ширині плечей стрибком перейти у фазу виносу стегна. У попереку дещо прогнутись, голову повернути в сторону передбачуваного удару, п'ятки та сідниці спрямовані в напрямку удару (назад). Виконати по 10 разів.

Стоячи обличчям до гімнастичної стінки права (ліву) нога зігнута, стопа атакуючої ноги знаходиться на перекладині вище коліна опорної ноги. Рухом тазу назад у напрямку передбачуваного удару вихід у фазу виносу стегна. Виконати по 10 разів кожною ногою.

Вихідне положення те саме як у попередній вправі. Після виходу у фазу виносу стегна виконати хльостке розгинання ноги у колінному суглобі зберігаючи висоту з фіксацією стопи в кінцевій фазі удару. Ударною атакуючою поверхнею $€$ «какато» (п'ятка). Виконати по 10 разів кожною ногою.

П’ята серія навчальних завдань - окремі частини цільової вправи і підвідні вправи:

Стоячи обличчям до гімнастичної стінки, спиною до партнера, права (ліва) нога зігнута у колінному суглобі, п’ятка спирається у живіт партнера. Відштовхування партнера від себе випрямляючі ногу, включаючи поштовх тазом, стегном і опорною ногою у кінцевій фазі. Партнер чинить посильний супротив. Виконати по 10 разів кожною ногою. 
Таблиця 1. Вимоги до виконання технічної дії «Удару ногою назад з розворотом»

\begin{tabular}{|c|c|}
\hline Бали & Критерії \\
\hline $\begin{array}{c}0,1 \\
\text { (незначна помилка) }\end{array}$ & $\begin{array}{l}\text { рухи виконуються з зайвою напругою; } \\
\text { відсутнє плавне цілісне виконання вправи вцілому; } \\
\text { незначні погрішності у рухах різними ланками тіла; } \\
\text { опускання рук з позиції захисту голови; } \\
\text { відсутній акцент у фінальній фазі удару; } \\
\text { невірно сформована ударна атакуюча поверхня «какато» (п’ятка); } \\
\text { відсутнє хльостке розгинання ноги у колінному суглобі. }\end{array}$ \\
\hline $\begin{array}{c}0,2 \\
\text { (істотна помилка) }\end{array}$ & $\begin{array}{l}\text { тулуб надмірно нахилений; } \\
\text { сильно підведені плечі у момент виконання техніки; } \\
\text { відсутній потужний обертальний рух стегном у бік удару і уміння координувати дію стегном } 3 \text { діями } \\
\text { руками і ногами; } \\
\text { порушено висоту виконання удару; } \\
\text { відсутня зміна положення області таза під час виконання фази виносу стегна. }\end{array}$ \\
\hline $\begin{array}{c}0,3 \\
\text { (груба помилка) }\end{array}$ & $\begin{array}{l}\text { значна втрата рівноваги; } \\
\text { розмахування руками у момент виконання техніки; } \\
\text { відсутній контроль дистанції під час виконання технічної дії; } \\
\text { порушена траєкторія руху удару; } \\
\text { відсутній поворот голови у напрямку передбачуваного удару; } \\
\text { сильно зігнуте або повністю випрямлене коліно опорної ноги у момент завдання удару; } \\
\text { відсутні фази виносу стегна або повернення ноги. }\end{array}$ \\
\hline
\end{tabular}

Із положення упору сточи на колінах поступово виконати фази удару ногою «уширо гері кекомі»: фаза виносу стегна (підняти коліно до живота), фаза випрямлення ноги назад з формуванням ударної поверхні, фаза повернення ноги (у фазу виносу стегна), фаза постановки ноги у вихідне положення. Ударною атакуючою поверхнею є «какато» (п'ятка). Те саме другою ногою. Кожна фаза виконується роздільно на окремий рахунок. Повний цикл виконати 10 разів кожною ногою.

Шоста серія навчальних завдань - виконання вправи в цілому:

Відпрацьовування техніки ударів ногами у повітря з чергуванням ніг із вихідного положення «Стійка ноги нарізно правою (лівою) вперед (куміте дачі)». Виконати вправи по 10 разів кожною ногою.

Те саме із стійки «куміте дачі» 3 просуванням кроком назад по прямій лінії. Виконати вправи по 10 разів кожною ногою.

Відпрацьовування техніки ударів ногами по лапам на точність із вихідного положення «Стійка ноги нарізно правою (лівою) вперед (куміте дачі)» 3 місця стоячі спиною до партнера. Виконати вправи по 10 разів кожною ногою.

Відпрацьовування техніки ударів ногами по лапам на точність із вихідного положення «Стійка ноги нарізно правою (лівою) вперед (куміте дачі)» 3 місця 3 поворотом. Виконати вправи по 10 разів кожною ногою.

Таблиця 2. План факторного експерименту типу $2^{2}$

\begin{tabular}{ccc}
\hline $\begin{array}{c}\text { Варіанти вико- } \\
\text { нання вправ }\end{array}$ & \multicolumn{2}{c}{ Режими навчання } \\
\cline { 2 - 3 } & $\begin{array}{c}\text { Кільість підходів, Інтервал відпочинку, c } \\
\text { разів }\left(\mathbf{X}_{\mathbf{1}}\right)\end{array}$ & \begin{tabular}{c}
$\left(\mathbf{X}_{2}\right)$ \\
\hline 1
\end{tabular} \\
2 & $2(-)$ & $60(-)$ \\
3 & $4(+)$ & $60(-)$ \\
4 & $2(-)$ & $120(+)$ \\
\hline
\end{tabular}

Дихання у всіх вправах необхідно співвідносити 3 темпом рухів і моментами напруги.

Перехід до наступної вправи здійснювався за умови вірного виконання попередньої вправи з точним дотриманням усіх технічні вимог. При цьому допускались незначні помилки. Рівень навченості техніці удару ногою назад з розворотом «уширо гері» (Y) оцінювався групою незалежних експертів у кількості трьох осіб за 10 -ти бальною шкалою. Знаходилось середнє арифметичне значення. Одноразова незначна помилка каралась відніманням 0,1 балу. Одноразова істотна помилка відніманням 0,2 бали. При одноразовій грубій помилці віднімалось 0,3 бали.

Для вирішення поставленої мети вивчався вплив різних варіантів виконання вправ, а саме: кількості підходів $\left(\mathrm{X}_{1}\right)$ та інтервалів відпочинку $\left(\mathrm{X}_{2}\right)$ на засвоєння техніки виконання удару ногою «уширо гері кекомі». Хлопці 10 років були поділені на чотири групи, згідно плану експерименту. Відмінності між групами в методиці проведення занять диктувалися умовами факторного експерименту, які представлені у таблиці 2. Нижні та верхні рівні пояснюючих змінних були обрані на основі даних Khudolii, Kapkan, Harkusha, Marchenko, \& Veremeenko (2020), Марченко \& Коваленко (2020), Марченко \& Тараненко 2020, також обмежувалися рамками тренувального заняття.

\section{Статистичний аналіз}

У роботі використані методики аналізу результатів математичного планування експерименту типу ПФЕ 2к (Кононюк, 2011; Khudolii \& Ivashchenko, 2014; Khudolii, Kapkan, Harkusha, Marchenko, \& Veremeenko, 2020).

Протокол дослідження був затверджений Етичним комітетом університету. Крім того, діти та їхні батьки були повністю інформовані про всі особливості дослідження, а підписаний документ про інформовану згоду було отримано від усіх батьків. 
ISSN 2708-7581 (Online). ISSN-L 2708-7573. Journal of Learning Theory and Methodology. 2021. Volume 2, Number 2

Таблиця 3. Результати аналізу ПФЕ 22

\begin{tabular}{ccccc}
\hline \multirow{2}{*}{ Серії навчальних занять } & Рівняння регресії для кодованих змінних & \multicolumn{2}{c}{$\begin{array}{c}\text { Відсотковий внесок у досягнення } \\
\text { цільового показника }\end{array}$} \\
\cline { 2 - 5 } & & $\mathbf{X}_{1}$ & $\mathbf{X}_{2}$ & $\mathbf{X}_{1} \mathbf{X}_{2}$ \\
\hline 1 & $\mathrm{Y}=9,017+0,479 \mathrm{X}_{1}-0,209 \mathrm{X}_{2}$ & 83,4 & 15,9 & 0,7 \\
2 & $\mathrm{Y}=9,216+0,177 \mathrm{X}_{1}-0,156 \mathrm{X}_{2}$ & 42,2 & 33,0 & 24,8 \\
3 & $\mathrm{Y}=8,862+0,282 \mathrm{X}_{1}+0,218 \mathrm{X}_{1} \mathrm{X}_{2}$ & 62,4 & 0,1 & 37,5 \\
4 & $\mathrm{Y}=9,029+0,156 \mathrm{X}_{1}+0,115 \mathrm{X}_{1} \mathrm{X}_{2}$ & 52,6 & 18,9 & 28,5 \\
5 & $\mathrm{Y}=8,946+0,364 \mathrm{X}_{1}+0,198 \mathrm{X}_{2}$ & 74,8 & 22,2 & 3,0 \\
6 & $\mathrm{Y}=8,977+0,479 \mathrm{X}_{1}+0,187 \mathrm{X}_{2}$ & 80,29 & 12,26 & 7,45 \\
\hline
\end{tabular}

\section{Результати}

У таблиці 3 наведені результати аналізу ПФЕ $2^{2}$.

Гіпотеза про однорідність дисперсій визначалась за допомогою критерію Кохрена та показала, що усі групи експериментальних даних отримані з однієї і тієї ж сукупності, та дають однакове розсіювання. Установлено, що дисперсії не відрізняються одна від одної для обраного рівня значимості 0,05 .

Регресійна залежність спостерігається протягом всього періоду виконання серій навчальних завдань. Кожна пояснююча змінна $\left(\mathrm{X}_{1}, \mathrm{X}_{2}\right)$ відіграє свою певну роль у зміні показника навченості вправі «Удар ногою назад з розворотом «уширо гері». Перевірка на адекватність за критерієм Фішера показала що розраховані коефіцієнти регресії статистично значимі (Fp<Fкр).

$\mathrm{y}$ «вправах для розвитку рухових здібностей» найбільший позитивний вплив має пояснююча змінна $\mathrm{X}_{1}$ «кількість підходів», її процентний внесок складає 83,4\%. Пояснююча змінна $\mathrm{X}_{2}$ «інтервал відпочинку» здійснює на результативну ознаку протилежний вплив (15,9\%). Для підвищення ефективності навчання необхідно збільшити кількість підходів до 4 а інтервал відпочинку достатньо утримувати в межах $60 \mathrm{c}$.

У серії «вихідні і кінцеві положення» на результативну ознаку (Y) позитивний вплив здійснюється пояснюючою змінною $\mathrm{X}_{1}$ «кількість підходів» $(42,2 \%)$. А пояснююча змінна $\mathrm{X}_{2}$ «інтервал відпочинку» чинить негативний вплив (33,0\%). Оптимальні досягнення результату у навчанні знаходяться в діапазоні 4 підходи, інтервал відпочинку складає $60 \mathrm{c}$.

У діях без яких неможливо виконати вправу найбільший позитивний вплив має пояснююча змінна $\mathrm{X}_{1}$ «кількість підходів» (62,4\%). Також спостерігається одночасний ефект взаємодії двох пояснюючих змінних $\mathrm{X}_{1} \mathrm{X}_{2}$, який характеризується позитивним впливом на вихідний параметр (37,5\%). Для збільшення параметру оптимізації необхідно тренуватися у режимі 4 підходи 3 інтервалами відпочинку $120 \mathrm{c}$.

У навчанні умінню управляти рухами необхідно дотримуватися режиму 4 підходи з інтервалами відпочинку 120 с. Дана рекомендація обгрунтовується отриманою математичною моделлю. Де відмічається позитивний вплив пояснюючої змінної $\mathrm{X}_{1}$ «кількість підходів» (52,6\%). Дещо менше ніж у третій серії спостерігається вплив взаємодії двох пояснюючих змінних $\mathrm{X}_{1} \mathrm{X}_{2}$ «інтервал відпочинку» та «кількість підходів» $(28,5 \%)$.

Отримане рівняння регресії для кодованих змінних у серії «окремі частини цільової вправи і підвідні впра- ви» указує на позитивний вплив пояснюючої змінної $\mathrm{X}_{1}$ «кількість підходів» $(74,8 \%)$ та пояснюючої змінної $\mathrm{X}_{2}$ «інтервал відпочинку» $(22,2 \%)$. Для досягнення оптимального рівня навченості удару ногою назад з розворотом «уширо гері» необхідно тренуватися у режимі 4 підходи з інтервалами відпочинку 120 c.

Навчальні завдання серії «виконання вправи в цілому» необхідно виконувати у режимі 4 підходи з інтервалами відпочинку 120 с для підвищення їх результату. Обрання такого режиму залежить від позитивного впливу пояснюючої змінної Х «кількість підходів» (80,29\%) і позитивного впливу пояснюючої змінної $\mathrm{X}_{2}$ «інтервал відпочинку» (12,26\%).

Таким чином, для навчання удару ногою назад з розворотом «уширо гері» хлопців 10 років рекомендуємо використовувати наступні найбільш сприятливі комбінації умов для розробленої нами програми:

1 серія - 4 підходи, інтервал відпочинку 60 c;

2 серія - 4 підходи, інтервал відпочинку 60 с;

3 серія - 4 підходи, інтервал відпочинку 120 c;

4 серія - 4 підходи, інтервал відпочинку 120 с;

5 серія - 4 підходи, інтервал відпочинку 120 с;

6 серія - 4 підходи, інтервал відпочинку 120 с.

\section{Дискусія}

У процесі дослідження припускалося, що від режиму чергування кількості підходів та інтервалів відпочинку залежить якість навчання вправі «Удар ногою назад з розворотом «уширо гері».

Отримані результати підтверджують позитивний ефект від програмованого навчання, яке дозволяє послідовно вирішувати навчальні задачі, раціонально використовувати засоби і методи (Khudolii, Kapkan, Harkusha, Marchenko, \& Veremeenko, 2020; Ivashchenko, Iermakov, \& Khudolii, 2021; Ivashchenko, 2020 та інші). Оптимізація умов навчання технічним діям дозволяє враховувати відмінності дітей молодшого шкільного віку (Марченко, 2006; Марченко \& Іванов, 2011; Ivashchenko, Nosko, Bartik, \& Makanin, 2020), які відрізняються недостатньо розвиненими взаємозв'язками між нейронами кори великих півкуль, швидкою стомлюваністю, мають недостатній розвиток довільної уваги. Об’єм уваги невеликий. У них недостатньо розвинута здібність концентрації уваги. Довго утримувати увагу на предметі, що вивчається вони ще не можуть. Напружена і зосереджена увага швидко приводить до нервового стомлення (Волков, 2016; Марченко \& Безпалько, 2020; Марченко \& Вердиш, 2021). 
Наше дослідження доповнює дані Марченко \& Тараненко (2020), Марченко \& Коваленко (2020), Ivashchenko, Iermakov, Khudolii (2021) про ефективність використання факторних планів під час вивчення закономірностей розвитку рухових навичок та Марченко (2017), Khudolii, Ivashchenko, Iermakov, Nosko, \& Marchenko (2019), Iermakov, Ivashchenko, Khudolii (2021) про розвиток pyхових здібностей у школярів молодших класів.

Отримані нові дані. Розроблена програма навчання техніці удару ногою «уширо гері кекомі». На основі результатів оцінки техніки виконання фізичної вправи отримані факторні моделі, які дають можливість визначити оптимальні режими навчання серії завдань, спрямованих на формування рухових навичок у хлопців 10 років. Використання отриманих результатів дасть можливість тренерам та вчителям фізичної культури обирати чітку стратегію прийняття рішень у процесі навчання дітей техніці ударів ногами.

\section{Література}

Марченко, С., \& Коваленко, К. (2020). Оптимізація режиму навчання техніки прямого удару ногою «має гері» в кіокушинкай карате хлопців 10 років. Журнал теорії та методології навчання, 1(1), 33-39. https://doi.org/10.17309/jltm.2020.1.05

Марченко, С., \& Тараненко, О. (2020). Керування ефективністю навчання техніки колового удару ногою «маваші гері» у кіокушинкай карате хлопців 10 років. Теорія та методика фізичного виховання, 20(4), 262268. https://doi.org/10.17309/tmfv.2020.4.10

Coral Falcó \& Isaac Estevan (2015). Biomechanics in Taekwondo: Practical Applications. Performance Optimization in Taekwondo: From Laboratory to Field, 10 30. https://doi.org/10.4172/978-1-63278-038-6-039

Агафонов, А.И., Осколков, В.А., \& Москвичев, Ю.Н. (2015). Модель обучения технике ударов ногами юных кикбоксеров на основе учета рациональных кинематических и динамических параметров движений. Ученые записки университета имени П.Ф.Лесгафта, 1(119), 14-18. https://doi.org/10.5930/issn.1994-4683.2015.01.119.p14-18

Estevan, I., Falco, C., Elvira, J.L.L., Vera-Garcia, F.J. (2015). Trunk and lower limb muscle activation in linear, circular and spin back kicks. Archives of Budo, 11, 243-250. https://hdl.handle.net/1956/12440

Wąsik J, Góra T. (2016). Kinematic taekwon-do back kick. Balt J Health Phys Act 8(4), 49-55. https://doi.org/10.29359/BJHPA.08.4.06

Gavagan, C.J, Sayers, M.G.L. (2017). A biomechanical analysis of the roundhouse kicking technique of expert practitioners: A comparison between the martial arts disciplines of Muay Thai, Karate, and Taekwondo. PLoS ONE, 12(8): e0182645. https://doi.org/10.1371/journal.pone.0182645

Błaszczyszyn, M., Szczęsna, A., Pawlyta, M., Marszałek, M., Karczmit, D. (2019). Kinematic Analysis of Mae-Geri Kicks in Beginner and Advanced Kyokushin Karate Athletes. Int. J. Environ. Res. Public Health, 16(17), 3155. https://doi.org/10.3390/ijerph16173155

Burke, D.T., al-Adawi, S., Burke, D.P., Bonato, P., Leong, C.M., (2017). The kicking process in tae kwon do: a

\section{Висновки}

Максимальний ефект результативної ознаки (Y) у серіях завдань розробленої програми навчання удару ногою «уширо гері кекомі» був отриманий від наступних режимів виконання фізичних вправ:

1 серія - 4 підходи, інтервал відпочинку 60 c;

2 серія - 4 підходи, інтервал відпочинку 60 c;

3 серія - 4 підходи, інтервал відпочинку 120 с;

4 серія - 4 підходи, інтервал відпочинку 120 с;

5 серія - 4 підходи, інтервал відпочинку 120 с;

6 серія - 4 підходи, інтервал відпочинку 120 с.

\section{Конфлікт інтересів}

Автори заявляють про відсутність конфлікту інтересів.

\section{References}

Marchenko, S., \& Kovalenko, K. (2020). Optimization of Teaching Boys Aged 10 Mae-Geri (Front Kick) Technique in Kyokushin Karate. Journal of Learning Theory and Methodology, 1(1), 33-39. https://doi.org/10.17309/jltm.2020.1.05

Marchenko, S., \& Taranenko, O. (2020). Managing the Effectiveness of Teaching Boys Aged 10 Mawashi-Geri (Roundhouse Kick) Technique in Kyokushin Karate. Teoriâ ta Metodika Fizičnogo Vihovannâ, 20(4), 262-268. https://doi.org/10.17309/tmfv.2020.4.10

Coral Falcó \& Isaac Estevan (2015). Biomechanics in Taekwondo: Practical Applications. Performance Optimization in Taekwondo: From Laboratory to Field, 1030. https://doi.org/10.4172/978-1-63278-038-6-039

Agafonov, A.I., Oskolkov, V.A., \& Moskvichev, Iu.N. (2015). Model obucheniia tekhnike udarov nogami iunykh kikbokserov na osnove ucheta ratcionalnykh kinematicheskikh i dinamicheskikh parametrov dvizhenii. Uchenye zapiski universiteta imeni P.F.Lesgafta, 1(119), 14-18. https://doi.org/10.5930/issn.1994-4683.2015.01.119.p14-18

Estevan, I., Falco, C., Elvira, J.L.L., Vera-Garcia, F.J. (2015). Trunk and lower limb muscle activation in linear, circular and spin back kicks. Archives of Budo, 11, 243-250. https://hdl.handle.net/1956/12440

Wąsik J, Góra T. (2016). Kinematic taekwon-do back kick. Balt J Health Phys Act 8(4), 49-55. https://doi.org/10.29359/BJHPA.08.4.06

Gavagan, C.J, Sayers, M.G.L. (2017). A biomechanical analysis of the roundhouse kicking technique of expert practitioners: A comparison between the martial arts disciplines of Muay Thai, Karate, and Taekwondo. PLoS ONE, 12(8): e0182645. https://doi.org/10.1371/journal.pone.0182645

Błaszczyszyn, M., Szczęsna, A., Pawlyta, M., Marszałek, M., Karczmit, D. (2019). Kinematic Analysis of Mae-Geri Kicks in Beginner and Advanced Kyokushin Karate Athletes. Int. J. Environ. Res. Public Health, 16(17), 3155. https://doi.org/10.3390/ijerph16173155

Burke, D.T., al-Adawi, S., Burke, D.P., Bonato, P., Leong, C.M., (2017). The kicking process in tae kwon do: a 
biomechanical analysis; running title: biomechanical analysis of taekwondo. Int Phys Med Rehab J., 1(1), 8-13. https://doi.org/10.15406/ipmrj.2017.01.00002

Khudolii, O., Kapkan, O., Harkusha, S., Marchenko, S., \& Veremeenko, V. (2020). Motor Skills Development: Optimization of Teaching Boys Aged 15 Press Headstand and Handstand. Teoriâ ta Metodika Fìzičnogo Vihovannâ, 20(1), 42-48. https://doi.org/10.17309/tmfv.2020.1.06

Ivashchenko, O., Iermakov, S., Khudolii, O. (2021). Modeling: ratio between means of teaching and motor training in junior school physical education classes. Pedagogy of Physical Culture and Sports, 25(3), 194-201. https://doi.org/10.15561/26649837.2021.0308

Марченко, C.I. (2017). Моделювання процесу розвитку спритності у хлопчиків 2-4 класів засобами рухливих ігор. Теорія та методика бізичного виховання, 17(2), 98-104. https://doi.org/10.17309/tmfv.2017.2.1194

Khudolii, O., Ivashchenko, O., Iermakov, S., Nosko, Y., \& Marchenko, S. (2019). Strength Abilities: Estimation of Immediate Training Effect of Strength Loads in Girls Aged 7 Years. Teoria ta Metodika Fizičnogo Vihovanna, 19(2), 98-104. https://doi.org/10.17309/tmfv.2019.2.06

Кононюк, А.Е. (2011). Основы научных исследований (Общая теория эксперимента): Монограбия : в 4 кн. Кн. 2. Киев : КНТ, 452. (in Ukrainian)

Худолій, О.М., \& Іващенко, О.В. (2014). Моделювання процесу навчання та розвитку рухових здібностей у дітей і підлітків: Монографія. Харків: ОВС, 320. (in Ukrainian)

Ivashchenko, O. (2020). Research Program: Modeling of Motor Abilities Development and Teaching of Schoolchildren. Teoriâ ta Metodika Fizičnogo Vihovannâ, 20(1), 32-41. https://doi.org/10.17309/tmfv.2020.1.05.

Марченко, С. (2006). Вікові особливості фізичного розвитку молодших школярів. Теорія та методика бізичного виховання, (6), 9-14. Retrieved from https:// www.tmfv.com.ua/journal/article/view/257

Марченко, С., \& Іванов, В. (2011). Оцінка фізичного розвитку хлопчиків 6-10 років у контексті сучасних завдань фізичного виховання. Теорія та методика фізичного виховання, (8), 10-13. Retrieved from https:// www.tmfv.com.ua/journal/article/view/730

Ivashchenko, O., Nosko, Yu., Bartik, P., \& Makanin, O. (2020). Gender-Related Peculiarities of 7-Year-Old Schoolchildren's Motor Fitness. Teoriâ ta Metodika Fizičnogo Vihovannâ, 20(4), 228-233. https://doi.org/10.17309/tmfv.2020.4.05

Волков, Л.В. (2016). Теория і методика дитячого та юнацького спорту. Вид.2-е,перероб. і доп. К.: Освіта України, 464.

Марченко, С., \& Безпалько, Д. (2020). Контроль і оцінка координаційних здібностей хлопчиків 7 років на етапі початкової підготовки в кіокушинкай карате. Журнал теорії та методології навчання, 1(2), 82-88. https://doi. org/10.17309/jltm.2020.2.06

Марченко, С., \& Вердиш, Я. (2021). Оцінка надійності та інформативності показників координаційної підготовленості хлопчиків 8 років. Журнал теоріі та методології навчання, 2(1), 21-28. https://doi. org/10.17309/jltm.2021.1.03 biomechanical analysis; running title: biomechanical analysis of taekwondo. Int Phys Med Rehab J., 1(1), 8-13. https://doi.org/10.15406/ipmrj.2017.01.00002

Khudolii, O., Kapkan, O., Harkusha, S., Marchenko, S., \& Veremeenko, V. (2020). Motor Skills Development: Optimization of Teaching Boys Aged 15 Press Headstand and Handstand. Teoriâ ta Metodika Fizičnogo Vihovannâ, 20(1), 42-48. https://doi.org/10.17309/tmfv.2020.1.06

Ivashchenko, O., Iermakov, S., Khudolii, O. (2021). Modeling: ratio between means of teaching and motor training in junior school physical education classes. Pedagogy of Physical Culture and Sports, 25(3), 194-201. https://doi.org/10.15561/26649837.2021.0308

Marchenko, S. (2017). Modeling Dexterity Development in 2nd-4th-grade Boys by Means of Active Games. Teoriâ ta Metodika Fizičnogo Vihovannâ, 17(2), 98-104. https://doi.org/10.17309/tmfv.2017.2.1194

Khudolii, O., Ivashchenko, O., Iermakov, S., Nosko, Y., \& Marchenko, S. (2019). Strength Abilities: Estimation of Immediate Training Effect of Strength Loads in Girls Aged 7 Years. Teoria ta Metodika Fizičnogo Vihovanna, 19(2), 98-104. https://doi.org/10.17309/tmfv.2019.2.06

Kononiuk, A.E. (2011). Osnovy nauchnykh issledovanii (Obshchaia teoriia eksperimenta): Monografiia: v 4 kn. Kn. 2. Kiev : KNT, 452. (in Russian)

Khudolii, O.M., \& Ivashchenko, O.V. (2014). Modeliuvannia protsesu navchannia ta rozvytku rukhovykh zdibnostei u ditei i pidlitkiv: Monohrafiia. Kharkiv: OVS, 320. (in Ukrainian)

Ivashchenko, O. (2020). Research Program: Modeling of Motor Abilities Development and Teaching of Schoolchildren. Teoriâ ta Metodika Fizičnogo Vihovannâ, 20(1), 32-41. https://doi.org/10.17309/tmfv.2020.1.05.

Marchenko, S. (2006). Vikovi osoblyvosti fizychnoho rozvytku molodshykh shkoliariv. Teoriâ ta Metodika Fizičnogo Vihovannâ, (6), 9-14. Retrieved from https://www.tmfv. com.ua/journal/article/view/257

Marchenko, S., \& Ivanov, V. (2011). Otsinka fizychnoho rozvytku khlopchykiv 6-10 rokiv u konteksti suchasnykh zavdan fizychnoho vykhovannia. Teoriâ ta Metodika Fizičnogo Vihovannâ, (8), 10-13. Retrieved from https://www.tmfv.com.ua/journal/article/view/730

Ivashchenko, O., Nosko, Yu., Bartik, P., \& Makanin, O. (2020). Gender-Related Peculiarities of 7-Year-Old Schoolchildren's Motor Fitness. Teoriâ ta Metodika Fizičnogo Vihovannâ, 20(4), 228-233. https://doi.org/10.17309/tmfv.2020.4.05

Volkov, L.V. (2016). Teoryia i metodyka dytiachoho ta yunatskoho sportu. Vyd.2-e,pererob. i dop. K.: Osvita Ukrainy, 464.

Marchenko, S., \& Bezpalko, D. (2020). Control and Assessment of 7-Year-Old Boys' Coordination Abilities at the Initial Training Stage in Kyokushin Karate. Journal of Learning Theory and Methodology, 1(2), 82-88. https://doi.org/10.17309/jltm.2020.2.06

Marchenko, S., \& Verdysh, Ya. (2021). Assessment of Reliability and Informativeness of Coordination Fitness Indicators of 8-Year-Old Boys. Journal of Learning Theory and Methodology, 2(1), 21-28. https://doi.org/10.17309/jltm.2021.1.03 
Sergii Iermakov, Olha Ivashchenko, Oleg Khudolii (2021). Strength abilities: assessment of cumulative training effects of strength loads of a series of classes in 8 years old boys. Journal of Physical Education and Sport, (JPES), 21(3), art.158, 1242-1250. https://doi.org/10.7752/ jpes.2021.s2158
Sergii Iermakov, Olha Ivashchenko, Oleg Khudolii (2021). Strength abilities: assessment of cumulative training effects of strength loads of a series of classes in 8 years old boys. Journal of Physical Education and Sport, (JPES), 21(3), art.158, 1242-1250. https://doi.org/10.7752/ jpes.2021.s 2158

\title{
IMPROVEMENT OF THE PROCESS OF TEACHING THE TECHNIQUE BOYS AGED 10 USHIRO GERI KEKOMI (BACK KICK)
}

\author{
Yehor Minenko $^{1 \mathrm{ABCD}}$, Svitlana Marchenko ${ }^{1 \mathrm{ABCD}}$ \\ ${ }^{1}$ H. S. Skovoroda Kharkiv National Pedagogical University \\ Authors' Contribution: A - Study design; B - Data collection; C - Statistical analysis; D - Manuscript Preparation; E - Funds Collection \\ Report. Article: 7 p., 6 tabl., 37 sources.
}

The purpose of the study is to substantiate the influence of different exercise options, namely: the number of approaches $\left(\mathrm{X}_{1}\right)$ and rest intervals $\left(\mathrm{X}_{2}\right)$ on the mastery of the technique of kicking back with a reversal of "wide geri" boys 10 years old.

Materials and methods. The study involved 32 boys aged 10 years. The children and their parents were informed about all the features of the study and agreed to participate in the experiment. Research methods were used to solve the tasks: study and analysis of scientific and methodological literature, pedagogical observation, timing of educational tasks, pedagogical experiment, methods of mathematical statistics, methods of mathematical planning of the experiment. The method of algorithmic instructions was used in the learning process.

Results. Explanatory variables $\left(\mathrm{X}_{1}, \mathrm{X}_{2}\right)$ play a role in changing the learning rate of the kick back exercise with a wide "geri" (Y) reversal throughout the experiment. The adequacy test by Fisher's test showed that the calculated regression coefficients were statistically significant $(\mathrm{Fp}<\mathrm{Fcr})$. Analysis of variance revealed the percentage effect of each explanatory variable $\left(\mathrm{X}_{1}\right.$, $\mathrm{X}_{2}$ ) in all series of the kickback training program with a reversal of "wide geri": 1 series - $\mathrm{X}_{1}(83.4 \%), \mathrm{X}_{2}$ (15.9\%); Series 2 - $\mathrm{X}_{1}$ (42.2\%), $\mathrm{X}_{2}(33.0 \%) ; 3$ series $-\mathrm{X}_{1}(62.4 \%), \mathrm{X}_{1} \mathrm{X}_{2}(37.5 \%) ; 4$ series - $\mathrm{X}_{1}(52.6 \%), \mathrm{X}_{1} \mathrm{X}_{2}(28.5 \%) ; 5$ series $-\mathrm{X}_{1}(74.8 \%), \mathrm{X}_{2}(22.2 \%) ; 6$ series $-\mathrm{X}_{1}(80.29 \%), \mathrm{X}_{2}(12.26 \%)$.

Conclusions. The maximum effect of the resultant sign (Y) in the series of tasks of the developed training program for kicking "wide geri kekomi" was obtained from the following modes of exercise: 1 series - 4 approaches, rest interval $60 \mathrm{~s} ; 2$ series -4 approaches, rest interval $60 \mathrm{~s} ; 3$ series -4 approaches, rest interval $120 \mathrm{~s} ; 4$ series -4 approaches, rest interval $120 \mathrm{~s} ; 5$ series - 4 approaches, rest interval 120 s; 6 series -4 approaches, rest interval $120 \mathrm{~s}$.

Key words: boys, training, physical exercises, programmed training, modes of performance of exercises, karate, kick, wide geri.

\section{Information about the authors:}

Minenko Yehor: egorminenko3@gmail.com; https://orcid.org/0000-0003-3193-1433; Department of Theory and Methodology of Physical Education, H. S. Skovoroda Kharkiv National Pedagogical University, Alchevskykh St, 29, Kharkiv, 61002, Ukraine.

Marchenko Svitlana: sport-svet1968@ukr.net; https://orcid.org/0000-0002-1013-9511; Department of Theory and Methodology of Physical Education, H. S. Skovoroda Kharkiv National Pedagogical University, Alchevskykh St, 29, Kharkiv, 61002, Ukraine.

Cite this article as: Minenko, Ye., \& Marchenko, S. (2021). Improvement of the Process of Teaching the Technique Boys Aged 10 Ushiro Geri Kekomi (Back Kick). Journal of Learning Theory and Methodology, 2(2), 91-97.

https://doi.org/10.17309/jltm.2021.2.06

Received: 18.04.2021. Accepted: 16.06.2021. Published: 30.06.2021

This work is licensed under a Creative Commons Attribution 4.0 International License (http://creativecommons.org/licenses/by/4.0). 